\title{
PENGEMBANGAN SISTEM PEMBINAAN DAN PENERIMAAN SUMBERDAYA MANUSIA TERBARU MELALUI FORMASI JABATAN FUNGSIONAL PEREKAYASA
}

\author{
Edy Syamsuddin ${ }^{1 *}$ \\ ${ }^{1}$ Badan Pengkajian dan Penerapan Teknologi, JL.MH.Thamrin No.8, Jakarta \\ ${ }^{*}$ Coresponding-Author : edy.syamsuddin@bppt.go.id
}

\begin{abstract}
ABSTRAK. Tujuan dari formasi jabatan fungsional perekayasa diperlukan untuk merancang jumlah personil perekayasa dalam suatu kegiatan kerekayasaan proses peningkatan jabatan karir bagi pegawai negeri sipil dalam melaksanakan tugas serta tanggung jawabnya di suatu unit atau instansi lingkup kegiatan kerekayasaan meliputi merancang menghitung, melakukan eksplorasi/ observasi/ pengujian produk, model atau sistem, dan melakukan proses perbaikan, pengoperasian maupun pemeliharaan dari suatu produk, model ataupun system. Formasi jabatan fungsional perekayasa dalam satu kegiatan per unit digunakan pendekatan asumsi konfigurasi organisasi kerekayasaan sesuai kebutuhan personil satu kegiatan pertahun yang identik dengan minimal berjumlah 14 orang. Proporsi empat jabatan perekayasa, yaitu perekayasa pertama: perekayasa muda: perekayasa madya: perekayasa utama dengan rasio berbanding antara 4:3:2:1. Rancangan formasi jabatan fungsional perekayasa pada satu instansi atau satu unit dapat digambarkan secara dinamik dengan menggunakan konsep personel requirement planning antara akumulasi jabatan perekayasa dengan waktu ke waktu dalam lima tahun.
\end{abstract}

Kata Kunci: Formasi Jabatan Fungsional Perekayasa, Kerekayasaan, Work Breakdown Structure, Personel Requirement Planning

\begin{abstract}
The purpose of the formation of engineering functional positions is needed to design the number of engineering personnel in an engineering activity in the process of advancing career positions for civil engineering employees in carrying out their duties and responsibilities in a unit or agency. The scope of engineering activities includes designing calculating, conducting exploration / observation / testing of products, models or systems, and carrying out the process of repair, operation and maintenance of a product, model or system. The formation of engineering functional positions in one activity per unit is used the engineering organization configuration assumption approach according to the personnel needs of one activity per year which is identical with a minimum number of 14 people. Proportion of four engineering positions [2,3], namely first engineer: young engineer: intermediate engineer: primary engineer with a ratio of 4: 3: 2: 1 . The design of the engineer functional position formation in one agency or one unit can be described dynamically by using the concept of personnel requirements planning between the accumulation of engineering positions over time within five years.
\end{abstract}

Keyword: Formation of functional engineering, Engineering position, Work Breakdown Structure, Personel Requirement Planning

\section{PENDAHULUAN}

\section{Latar Belakang}

Perekayasa adalah jabatan yang mempunyai ruang lingkup, tugas, tanggung jawab, dan wewenang untuk melakukan kegiatan teknologi dalam suatu kelompok kerja fungsional pada bidang penelitian terapan, pengembangan, perekayasaan, dan pengoperasian yang diduduki oleh Pegawai Negeri Sipil dengan hak dan kewajiban yang diberikan secara penuh oleh pejabat yang berwenang. Sifat dari pekerjaan Perekayasaan adalah kegiatan penerapan ilmu pengetahuan dan teknologi 
dalam bentuk desain dan rancang bangun untuk menghasilkan sistem, model, nilai, produk dan/ atau proses produksi dengan mempertimbangkan keterpaduan sudut pandang dan/atau konteks teknikal, fungsional, bisnis, sosial budaya dan estetika, dalam suatu kelompok kerja fungsional.

Pada dasarnya proses kegiatan kerekayasaan digerakkan oleh sumberdaya manusia yakni personil yang mempunyai peran, jabatan, tingkat keahlian, disiplin ilmu serta bekerja sama secara kelompok untuk menghasilkan sesuatu karya yang saling bersinergi.Penyusunan proporsi kebutuhan personil dalam sistem ketata rekayasaan berbanding lurus secara eksponensial dengan jumlah lingkup kegiatan, waktu proses pengerjaan. Proporsi ini tidak berbanding secara linear karena ada sebagian personil dari satu kegiatan dapat merangkap masuk dari kegiatan lainnya, sesuai dengan bidang ke ahliannya atau ilmuannya dan tidak berada dalam satu kelompok yang sama dalam kegiatan tersebut, tetapi dapat masuk dalam kegiatan lainnya.

Fungsi rancangan kebutuhan personil ini bersifat dinamik artinya, setiap penyusunan personil disesuaikan dengan ketersedian personil pada saat itu (bezetting personel), sedangkan kebutuhan personil JFP pada tahun berjalan adalah parameter Zi(t). Penyusunan kebutuhan personil dengan menggunakan matriks transformasi merupakan salah satu komponen tools untuk melakukan merancang jumlah kebutuhan personil yang bergerak secara dinamis sesuai waktu pertahun, perubahan jenjang jabatannya, perubahan peran dan lingkup tanggung jawab pekerjaannya.

Rancangan personil menggunakan matriks transformasi dapat menghasilkan perubahan kebutuhan berdasarkan posisi peran dan jabatan dari personil tersebut yang bergerak dari waktu ke waktu, dalam rancangan disini perubahan waktu ke waktu untuk sepuluh tahun kedepan. Perubahan kebutuhan berdasarkan peran dan jabatan fungsional Perekayasa disesuaikan dengan kondisi ketersedian anggaran persyaratan rekrutmen pegawai, dan waktu proses bagi ketersedian pegawai baru yang akan mengembangkan karirnya melalui jalur jabatan fungsional Perekayasa. Penyusunan rancangan kebutuhan personil jabatan fungsional Perekayasa tersebut harus selaras dengan peran, aktivitas dan fungsi dari tugas kerekayasaan bagi kepentingan unit kerjanya dalam menjalankan tugas. Rancangan kebutuhan personil dalam jabatan fungsional perekayasa harus mengacu pada suatu penyelenggaraan kegiatan di unit atau instansi masing- masing, karena mereka merupakan seorang pejabat fungsional, maka fungsi serta peran dalam lingkup kegiatan kerekayasaan harus mampu menghasilkan minimal seperempatnya pertahun dari angka kredit yang harus dicapai ke jenjang lebih tinggi. Selain itu suatu unit atau instansi dapat dikatakan bekerja dengan tata kerekayasaan jika dalam kegiatannya mengandung 4 (empat) elemen atau unsur kegiatan, yaitu; desain/ merancang, menghitung/ komputasi, menguji/ observasi/ eksplorasi dan perbaikan, operasi dan pemeliharaan dari suatu produk, model ataupun sistem. Dari keterlibatan kegiatan kerekayasaan dalam tiga elemen di unit atau instansi tersebut.

Konsep matriks transformasi antara peran, jabatan bagi personil yang terlibat dalam kegiatan kerekayasaan merupakan salah satu metode untuk menyusun rancangan kebutuhan personil untuk suatu kegiatan kerekayasaan dalam tahun berjalan. Penyusunan rancangan tidak bersifat solid, artinya perubahan penyusunan rancangan dapat diubah ubah berdasarkan tercapainya jumlah personil pada tahun berikutnya, perubahan juga pada peran maupun jabatan , masa berakhir jabatan fungsional perekayasa seseorang yang berhenti maupun pensiun. Fungsi penyusunan rancangan yang bersifat dinamik, yaitu waktu dengan mengukur kegiatan yang sudah dirancang dalam RENSTRA (lima tahunan) akumulasi proses kegiatan yang mengandung sedikitnya dua elemen atau unsur kerekayasaan menjadi titik tolak untuk mengukur jumlah kebutuhan personil. Dari kegiatan RENSTRA dapat diuraikan dalam RKT (Rencana Kinerja Tahunan) atau direfleksikan dalam satu atau lebih kegiatan dalam tahunan. 
Penyusunan kegiatan yang mengandung elemen/unsur kerekayasaan akan membutuhkan sejumlah personil, sebagai asumsi untuk satu kegiatan minimal dibutuhkan 14 orang personil Jabatan fungsional perekayasa dengan diasumsikan bahwa tipe WBS nya pada katagori "B" . merupakan nilai rata-rata (mean value) dari rancangan kebutuhan personil jabatan fungsional perekayasa yang diasumsikan secara rafa-rata sekitar 14 orang. Konfigurasi 3 orang "troika", dua orang "kepala kelompok", tiga orang " Kepala" dan enam orang ' Insinyur staf'.

Proses narasi berikutnya jika sudah diketahui jumlah kegiatan di suatu unit, maka secara akumulasi pertahun serta dalam lima tahun kedepan jumlah kegiatan, tingkat pencapaian (kinerja), jumlah kebutuhan personil pertahun, kebutuhan dana, serta penyelesaian proyek atau program (kerekayasaan) Akumulasi kebutuhan personil dalam tahun berjalan mengikuti pola rumus yang dijelaskan dalam metodologi.

Aspek-aspek apa saja yang dicakup oleh penyusunan rancangan jabatan fungsional Perekayasa, yaitu menentukan nilai parameter rancangan kebutuhan pegawai secara akulumasi $\mathrm{Y}_{\mathrm{i}}$, untuk menjalankan fungsi kegiatan kerekayasaan pertahun, melakukan inventarisasi jumlah pegawai berdasarkan kemampuan, peran dalam ilmu maupun bidang pekerjaannya. Berikutnya dari konfigurasi kebutuhan personil dalam satu tahun, akan tergambar kekurangan atau lowongan kebutuhan pegawai baru untuk rekrutmen mula serta proses pegawai baru ini untuk menjadi pejabat fungsional Perekayasa.

\section{Asumsi dalam Lingkup Formasi Jabatan Fungsional Perekayasa}

Asumsi lingkup formasi jabatan Fungsional Perekayasa meliputi proses kegiatan kerekayasaan sebagai berikut:

Tabel 1. Lingkup formasi jabatan fungsional perekayasa

\begin{tabular}{|c|c|c|c|c|}
\hline No & Elemen & No & Substansi & Keterangan \\
\hline \multirow[t]{2}{*}{1} & Desain & 1 & Desain & $\begin{array}{l}\text { Sintesa, desain konseptual, desain awal } \\
\& \text { desain rinci }\end{array}$ \\
\hline & & 2 & Analisa & $\begin{array}{l}\text { Analisa desain, kebijakan sistem } \\
\text { teknologi, strategi bisnis, audit \& } \\
\text { standardisasi, sales \& distribusi, } \\
\text { marketing }\end{array}$ \\
\hline 2 & Komputasi & 3 & Komputasional & $\begin{array}{l}\text { Penurunan, pengembangan, diskritisasi } \\
\& \text { simulasi model numerik }\end{array}$ \\
\hline \multirow[t]{2}{*}{3} & Testing & 4 & Experimental & $\begin{array}{l}\text { Pengujian komponen, subskala } \\
\text { (subscale), skala penuh (fullscale) serta } \\
\text { survey, observasi dan explorasi }\end{array}$ \\
\hline & & 5 & Produksi/ konstruksi & $\begin{array}{l}\text { Pembuatan, perakitan komponen (sub } \\
\text { assembly) \& integrasinya menjadi produk } \\
\text { teknologi lengkap (general assembly) }\end{array}$ \\
\hline 4 & Improvement & 6 & $\begin{array}{l}\text { Maintenance } \\
\text { Operasi }\end{array}$ & $\begin{array}{l}\text { Perawatan, perbaikan \& modifikasi serta } \\
\text { pengoperasian produk teknologi }\end{array}$ \\
\hline
\end{tabular}

Tugas pokok tersebut dibagi sesuai dengan jenjang jabatan perekayasa. Pejabat Perekayasa dengan jenjang jabatan yang lebih tinggi, apabila diperlukan dapat mengerjakan kegiatan Kerekayasaan yang menjadi tugas dan tanggung jawab pejabat perekayasa satu jenjang dibawahnya, begitu juga sebaliknya.

\section{Tujuan dan Fungsi}

Tujuan dari menyusun rancangan jabatan fungsional perekayasa adalah untuk mempersiapkan kebutuhan jumlah personil yang terlibat dalam kegiatan kerekayasaan serta merencanakan peningkatan karir jabatan fungsional Perekayasa di suatu unit atau instansi 
pemerintah. Matriks transformasi merupakan suatu metodologi untuk menterjemahkan program kegiatan kerekayasaan dan kebutuhan personil jabatan fungsional perekayasa yang didasari oleh peran dan tugas Perekayasa untuk menyelesaikan program kegiatan kerekayasaan di suatu proyek/program.

Fungsi rancangan jabatan fungsional perekayasa yaitu untuk menghasilkan para perekayasa dalam setiap jenjang dalam mengetahui kompetensi, pengetahuan, dan wawasan dari tugas seorang perekayasa yang bekerja berdasarkan "team work". Lingkup kegiatan meliputi:

a. Melaksanakan kegiatan penelitian terapan, pengembangan, perekayasaan dan pengoperasian;

b. Melaksanakan penyusunan pedoman dan pembuatan laporan dalam organisasi fungsional kerekayasaan.

\section{Sasaran}

Menghasilkan rancangan formasi jabatan fungsional perekayasa di suatu unit atau instansi dalam periodik waktu berjalan sampai sepuluh tahun kedepan sasaran meliponid peranan, strata jabatan fungsional Perekayasa yang terbagi dalam empat jenjang, yaitu perekayasa pertama, perekayasa muda, perekayasa madya dan Perekayasa Utama. Hasil dari sasaran merupakan konfigurasi tahun ke tahun kebutuhan formasi jabatan fungsional Perekayasa.

Hasil keluaran dari sasaran ini merupakan konfigurasi jabatan fungsional Perekayasa di suatu unit atau instansi yang bersifat tentative, serta dapat berubah dalam periode tahun- ke tahun. Rancangan menggunakan konsep matriks transformasi akan menghasilkan fase perubahan jabatan fungsional perekayasa seseorang secara dinamis, disertai juga perubahan kenaikan jenjang, perubahan berhentinya seseorang dari jabatannya maupun mencapai tingkat pensiun.

\section{Parameter Mono Activity X;}

Menentukan paremeter mono activity $X_{i}$ adalah nilai dasar asumsi jumlah formasi Jabatan Fungsional dengan akumulasi personil berjumlah 14 orang untuk satu kegiatan dengan jumlah WBS sama dengan dua $i=1,2,3,4$ yaitu strata atau jenjang jabatan perekayasa, dari perekayasa pertama, perekayasa muda, perekayasa madya dan perekayasa utama. Asumsi parameter dasar ini merupakan konfigurasi dari organisasi kerekayasaan tipe B dengan 2 WBS yang terdiri dari 3 (tiga) orang troika, yaitu Kepala Program, Insinyur Kepala, dan Program Manager, 2(dua) orang kepala kelompok, 3 (tiga) orang kepala dan 6 (enam) orang insinyur staf.

\section{Parameter- Multi Activity $\mathbf{Y}_{\mathrm{i}}$}

Menentukan paremeter multi activity $\mathrm{Y}_{\mathrm{i}}^{\mathrm{t}}$ adalah nilai asumsi jumlah formasi Jabatan Fungsional dengan akumulasi personil berjumlah lebih dari 18 orang untuk minimal dua kegiatan. Jumlah WBS dalam satu kegiatan minimal dua WBS. Dalam struktur WBS melibatkan para personil dengan strata atau jenjang jabatan perekayasa, yaitu dari perekayasa pertama, perekayasa muda, perekayasa madya dan perekayasa utama. Asumsi bahwa untuk satu kegiatan dengan konfigurasi dari organisasi kerekayasaan tipe B dengan 2 WBS yang terdiri dari 3 (tiga) orang troika, yaitu Kepala Program, Insinyur Kepala, dan Program Manager, 2(dua) orang kepala kelompok , 3 (tiga)orang kepala dan 6 (enam) orang insinyur staf.

Formula untuk menghitung akumulasi kegiatan pada tahun berjalan dengan kegiatan lebih dari satu yaitu:

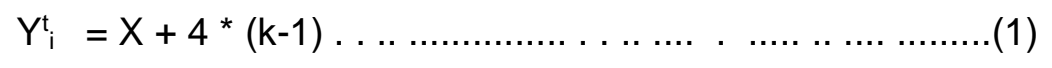

dimana $k=1,2,3,4, \ldots(n-1), k$ adalah jumlah kegiatan di unit atau instansi pemerintah 


\section{METODE}

Proses pentahapan dalam menyusunan rancang formasi jabatan fungsional perekayasa dapat dilihat pada Gambar 1

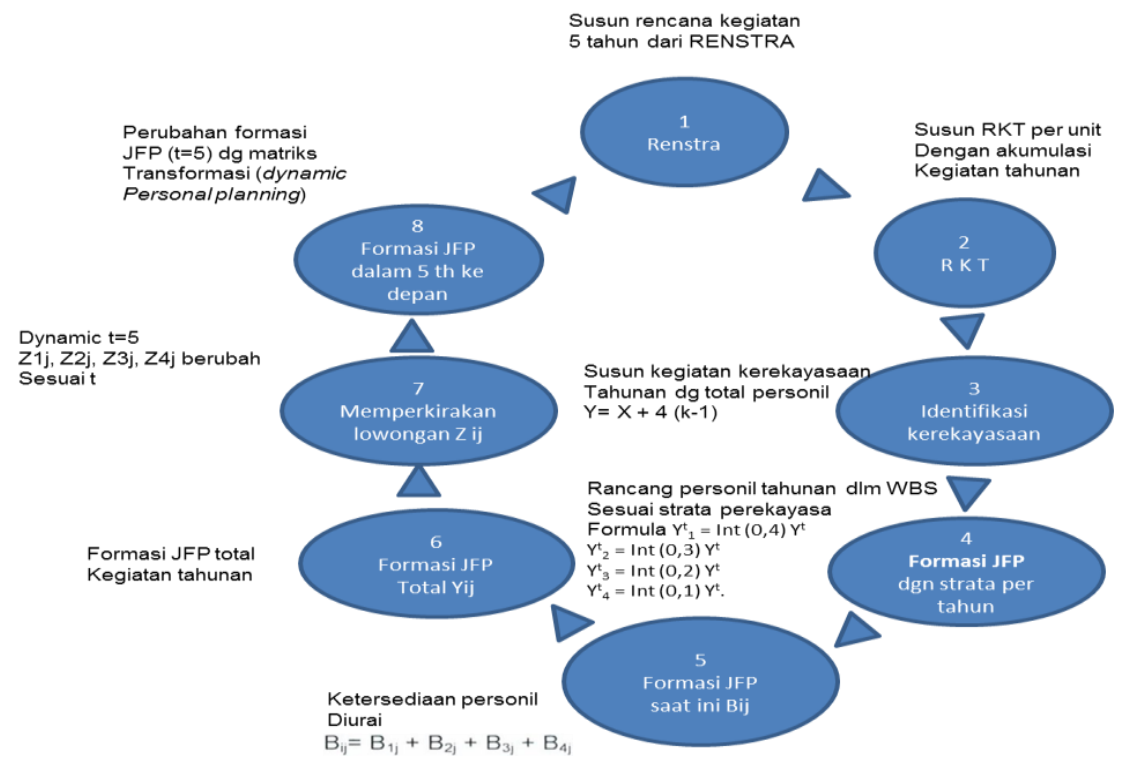

Gambar 1. Tampilan pemasaran melalui media sosial

\section{Menyusun Akumulasi Kegiatan Tahunan}

Dalam menyusun kebutuhan total dari personil pertahunnya, dimulai dengan menyusun secara akumulasi kegiatan pertahunnya, proses perencanaan awal umumnya dimulai dari penyusunan rencana strategi dari suatu unit atau instansi selama lima tahun kedepan, proses pentahapannya dapat dilihat pada Gambar 2.

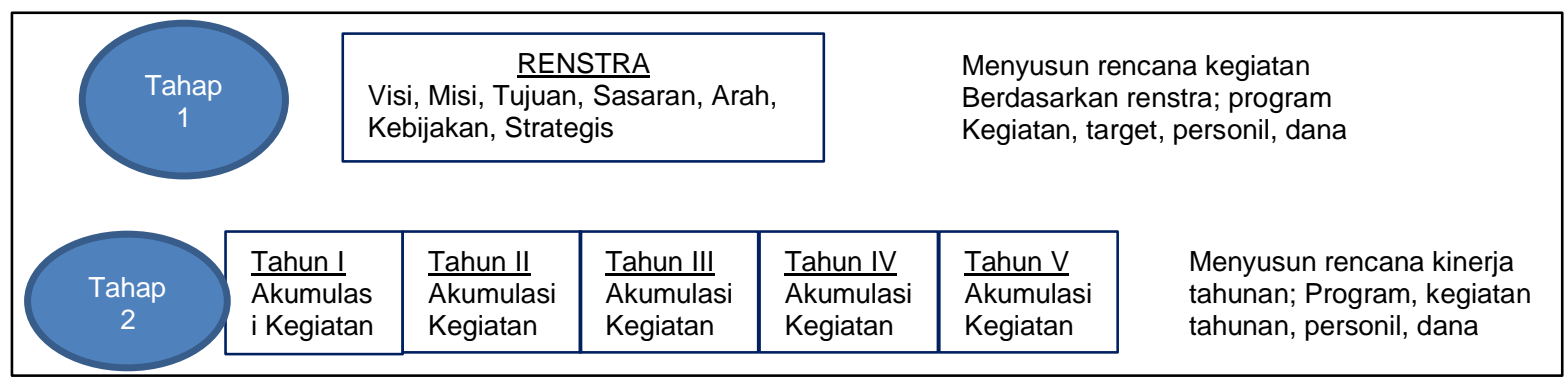

Gambar 2. Proses pentahapan dalam menghitung akumulasi kegiatan pertahun atau dalam lima tahun kedepan

Pelaksanaan pentahapan dalam menghitung akumulasi kegiatan dilakukan dengan menyusun sejum lah kegiatan dalam rencana strategis lima tahun kedepan seperti terlihat pada tahap pertama yakni menusun program kegiatan, target yang akan dicapai, merancang kebutuhan personil, memperhitungkan biaya yang semua program ini disesuaikan antara capaian dengan standar kompetensi kegiatan yang dijelaskan dalam RENSTRA kesesuaian dengan harapan dari rencana strateg i kegiatan ini diperoleh dengan mengestimasi beberapa kegiatan yang dihitung secara akumulasi.

Pada tahap kedua merupakan tahap untuk menyusun rencana kinerja tahunan, Tugas pokok dan fungsi dari unit atau instansi diurai menjadi beberapa kinerja yang harus dicapai oleh suatu unit atau instansi. Proses pencapaian suatu kinerja yang mengandung elemen kerekayasaan dapat di implementasikan menjadi suatu kegiatan. Pada tahap kedua yakni menyusun rencana kinerja tahunan diurai yang mengandung elemen/unsur kerekayasaan yang diurai menjadi beberapa 
kegiatan yang membutuhkan sejumlah personil yang sebagian besar pejabat fungsional perekayasa, selain kebutuhan personil ini dalam penyusunan kinerja tahunan ini juga memerlukan kebutuhan pendanaan Selain kebutuhan pendanaan , diperlukan jangka waktu penyelesaian suatu proyek, dalam penyusunan ini diasumsikan bahwa dalam satu kegiatan secara rata- rata terlibat 14 orang perekayasa dengan konfigurasi Struktur Rincian Kerja (WBS ) dengan tipe B, jika program atau proyek lebih dari satu tahun , maka konfigurasi perhitungan formasi jabatan fungsional perekayasa yang diukur dengan menggunakan pola tahunan. Untuk memperkirakan jumlah kegiatan pertahun ini diukur dengan basis atau dasar dari satu kegiatan dengan notasi $\mathrm{Xi},=14$ orang.

Hasil dari sejumlah kegiatan yang muncul dari tahun ke tahun akan diperhitungkan secara akumulasi serta dapat diperkirakan sejumlahkebutuhan personildalam menyelesaikan kegiatan tersebut. Estimasi dengan konfigurasi formasi jabatan fungsional perekayasa bagi satu kegiatan diasumsikan sebanyak 14 orang, apabila jumlah kegiatan lebih dari satu, maka jumlah yang terbanyak untuk menambah jumlah personil adalah pada tingkat perekayasa pertama maupun perekayasa muda, penambahan ataupun perhitungan penambahan jumlah personil di bahas pada alinea berikutnya.

\section{Menyusun Jumlah Kebutuhan Personil JF Perekayasa Kegiatan Tahunan}

Setelah selesai proses pentahapan kedua, yaitu dengan diperolehnya jumlah kegiatan yang terkait dengan kerekayasaan , jumlah kegiatan dari suatu unit atau instansi kemungkinan besar lebih dari satu kegiatan kerekayasaan, maka dasar darimenentukan sejumlah kebutuhan personilnya menggunakan rumus sebagai berikut .

$$
\mathrm{Y}_{1}=\mathrm{X} ;+4(\mathrm{k}-1)
$$

dimana: $\mathrm{k}=$ kegiatan kerekayasaan , $\mathrm{k}=1,2,3,4, . \ldots \mathrm{n}, \mathrm{X}_{1},=14$ orang (asumsi)

Jumlah kebutuhan personil pertahun $\mathrm{Y}_{\mathrm{i}}^{\mathrm{t}}$, diperoleh dengan persamaan (1) artinya jika kegiatan (k) menjadi dua kegiatan, maka kebutuhan personil pertahunnya mencapai 18 orang, demikian pula kegiatan menjadi tiga, maka kebutuhan personil pertahunnya mencapai 22 orang, perubahan personil ini mengikuti fungsi deret hitung, dimana penambahan kegiatan kegiatan lebih dari satu bertambah menjadi 4 orang .

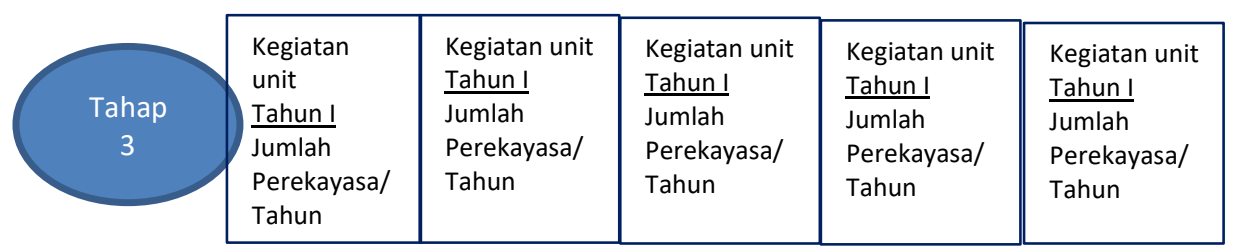

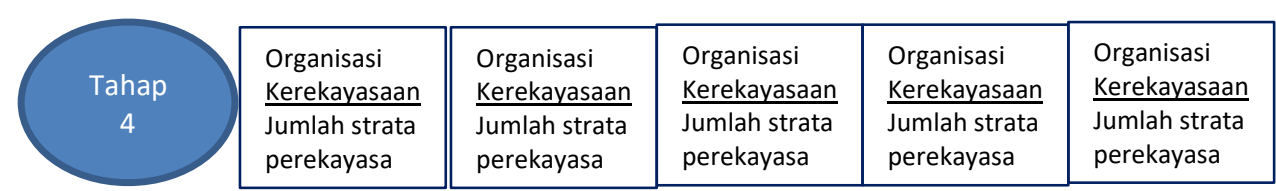

\author{
Menyusun jumlah Perekayasa \\ per tahun; Identifikasi element \\ kerekayasaan (3 elemen \\ Satu kegiatan, perekayasa, dana) \\ Formula : $Y=X+4 *(k-1)$, \\ $X=14$ (org) \\ Menyusun formasi JFP total \\ kegiatan \\ Tahunan; strata perekayasa \\ $(1,2,3,4)$ \\ serta diakumulasi per tahun \\ Formula $Y=\operatorname{lns}(0,4) Y$ \\ $Y=\operatorname{lns}(0,3) Y$ \\ $Y=\operatorname{Ins}(0,2) Y$ \\ $Y=\operatorname{Ins}(0,1) Y$
}

Gambar 3. Menyusun jumlah personil yang dibutuhkan dalam tahun berjalan

Penyusunan kebutuhan formasi jabatan fungsional sesuai dengan strata atau jenjang perekayasa terdistribusi dengan pola 4: 3: 2: 1, yaitu pola kebutuhan strata perekayasa pertama, perekayasa muda, perekayasa madya dan perekayasa utama. Pola persamaan dapat dilihat dalam persamaan 2), sebagai berikut: 


$$
\begin{aligned}
& Y^{\mathrm{t}}{ }_{1}=\operatorname{Int}(0,4) \mathrm{Y}^{\mathrm{t}} \\
& \mathrm{Y}^{\mathrm{t}}{ }_{2}=\operatorname{Int}(0,3) \mathrm{Y}^{\mathrm{t}} \\
& \mathrm{Y}^{\mathrm{t}}{ }_{3}=\operatorname{Int}(0,2) \mathrm{Y}^{\mathrm{t}} \\
& \mathrm{Y}^{\mathrm{t}}{ }_{4}=\operatorname{Int}(0,1) \mathrm{Y}^{\mathrm{t}} .
\end{aligned}
$$

Dimana $\mathrm{Y}_{1}^{\mathrm{t}}=$ perekayasa pertama, $\mathrm{Y}_{2}^{\mathrm{t}}=$ perekayasa muda, $\mathrm{Y}_{3}=$ perekayasa madya $\mathrm{Y}_{4}^{\mathrm{t}}=$ perekayasa utama

Penggunaan persamaan 2) diatas dimaksud untuk merancang formasi jabatan fungsional perekayasa yang dibutuhkan, serta konfigurasi formasi jabatan fungsional ini merefleksikan posisi peran dan tanggung jawab bagi seseorang perekayasa dalam melibatkan pekerjaan antara satu dengan yang lainnya secara bersama di dalam suatu lingkup WBS secara totalitas dari kebutuhan personilnya. Jika kebutuhan personil ini, masih ada kekurang personil yang tidak mempunyai jabatan fungsional perekayasa, maka personil lainnya masih dapat dipergunakan, sepanjang personil yang non JFP ini dapat mengerjakan tugas-tugasnya. Fungsi rancangan total kebutuhan formasi JFP ini bersifat dinamis atau tidak rigid, karena seseorang perekayasa dapat naik perannya, selain itu posisi dapat bekerja di WBS lain ataupun dalam kegiatan lainnya.

\section{Menyusun Ketersedian Formasi JFP Saat ini}

Sebelum menyusun konfigurasi kebutuhan formasi JFP, suatu unit atau instansi dapat melakukan inventarisasi kondisi personil yang sudah eksis dilembaganya, seperti tergambar pada tahap lima dan proses penyusunan dapat dilihat pada Gambar 4.

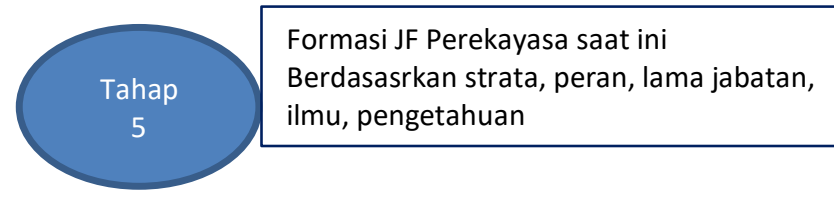

Menyusun formasi JFP saat ini; identifikasi JFP sesuai strata sampai dengan saat ini Ketersediaan Perekayasa persamaan (1) Formula : $\mathrm{Bij}=\mathrm{B} 1 \mathrm{j}+\mathrm{B} 2 \mathrm{j}+\mathrm{B} 3 \mathrm{j}+\mathrm{B} 4 \mathrm{j}$ Dimana $\mathrm{i}=$ strata jenjang, $\mathrm{j}=$ lama jabatan

Gambar 4. Tahapan Inventarisasi Formasi JFP sampai dengan saat ini

Cara untuk menghitung ketersediaan formasi jabatan fungsional perekayasa yang eksis di unit atau suatu instansi pemerintah dengan notasi sebagai Bij [1]. Proses penyusunannya menggunakan formulasi persamaan 3) sebagai berikut:

$$
B_{i j}=B_{1 j}+B_{2 j}+B_{3 j}+B_{4 j}
$$

dimana: $\mathrm{B}, 1=$ ketersedian formasi jabatan fungsional perekayasa saat ini

$\mathrm{B}_{1 \mathrm{j}}=$ ketersedian JF Perekayasa pertama dgn masa kerja $\mathrm{j}$, dst

$\mathrm{j}$ = masa kerja $\mathrm{j}$ abatan fungsional perekayasa sampai dengan saat ini

contoh: Konfigurasi dan ketersediaan formasi jabatan fungsional perekayasa s/d saat ini

Tabel 2. Konfigurasi dan ketersediaan formasi saat ini

KONFIGURASI FORMASI JFP Saat ini

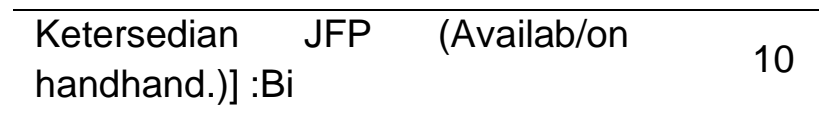

-Perekayasa pertama : $\mathrm{B}_{1}$

-Perekayasa Muda : $\mathrm{B}_{2}$ 
-Perekayasa Madya : $\mathrm{B}_{3}$

Menyusun Konfigurasi Kebutuan Formasi JFP Kegiatan 5 Tahunan [1,2,3]. Setelah diketahui posisi atau jumlah formasi jabatan fungsional perekaysaa saat ini melalui suatu proses inventarisasi jumlah perekayasanya disuatu unit berdasarkan strata atau jenjang dengan lama menjabat dalam JFP ini, maka proses berikutnya yaitu sebagai berikut sebagaimana terlihat pada Gambar 5.

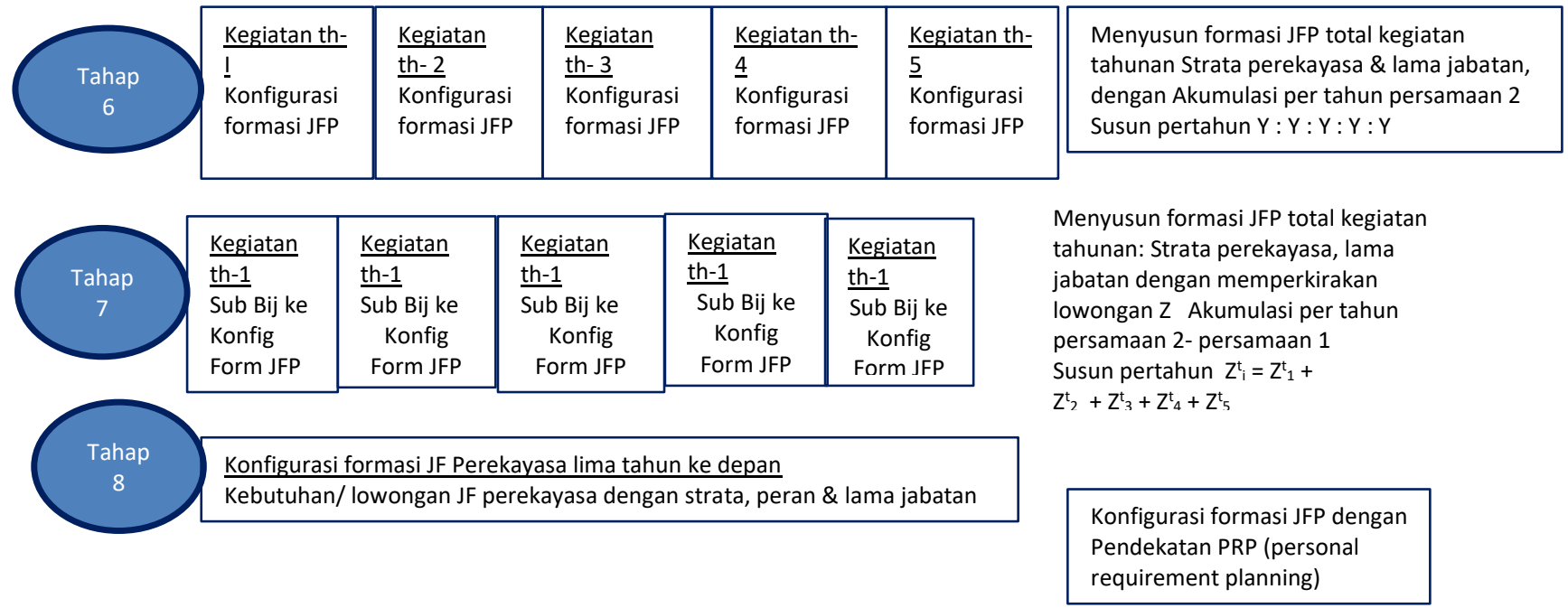

Gambar 5. Tahapan Menyusun Konfigurasi Kebutuan Formasi JFP Kegiatan 5 Tahunan

Proses pentahapan penyusunannya konfigurasi formasi kebutuhan jabatan fungsional perekayasa adalah sebagai berikut: Menyusun rencana total kebutuhan formasi jabatan fungsional perekayasa dalam konfigurasi lima tahun kedepan di rumuskan dalam persamaan 2), diuraikan untuk lima tahun kedepan serta dimasukan pada peta matriks sebagai berikut:

Tabel 3. Konfigurasi Formasi tahun ke tahun

\begin{tabular}{llllll}
\hline Konfigurasi Formasi JFP & Th-1 & Th-2 & Th-3 & Th-4 & Th-5 \\
\hline Rencana JFP (gross Req) & 18 & 18 & 22 & 22 & 22 \\
Perekayasa Pertama : $\mathrm{Yt}_{1}$ & 9 & 9 & 10 & 10 & 10 \\
Perekayasa Muda $\mathrm{Y}_{2}{ }_{2}$ & 5 & 5 & 6 & 6 & 6 \\
Perekayasa Madya $\mathrm{Yt}^{\mathrm{t}}{ }_{3}$ & 3 & 3 & 4 & 4 & 4 \\
Perekayasa Utama $\mathrm{Yt}_{4}$ & 1 & 1 & 2 & 2 & 2 \\
\hline
\end{tabular}

Menghitung nilai lowongan atau kekurangan formasi jabatan fungsional perekayasa atau dapat dikatakan sebagai kebutuhan bersih (nett requirement) disimulasikan dengan Z, menentukan nett requirement dengan menggunakan formasi dari persamaan 4) sebagai berikut:

$$
Z_{i}^{t}=Y_{i}^{t}-B_{i j}
$$

dimana: $Z$ = kebutuhan formasi (nett requirement) JFP dalam tahun berjalan $\mathrm{t}=$ tahun berjalan, $\mathrm{j}=$ lama menjabat JFP

Menentukan konfigurasi formasi jabatan fungsional perekayasa dari tahun ke tahun menggunakan konsep Personel Requirement Plannning (PRP), konsep ini merupakan pola perhitungan dari pendekatan Material Requirement Planning (MRP). Aplikasi perhitungannya digunakan matriks transformasi dalam merancangan kebutuhan personil untuk lima tahun kedepan. 
Akurasi perhitungan bersifat dinamik, yaitu membuat konfigurasi ini, digunakan persamaan 1), persamaan 2), persamaan 3) dan persamaan 4). Contoh perhitungan dengan menggunakan perhitungan matriks transformasi dan ke-empat persamaan tersebut diatas dapat di lihat pada simulai penyusunan formasi jabatan fungsional perekayasa.

\section{SIMULASI DAN PEMBAHASAN FORMASI JFP}

Untuk menyusun kebutuhan formasi jabatan fungsional perekayasa digunakan suatu contoh dari dua kegiatanyang bersifat soft engineering dan hard engineering. Sebagai contoh diambil dari program suatu unit Pusdiklat dan unit pelaksana teknis yang lingkup kegiatannya untuk melakukan pengujian atau pengembangan produk.

\section{HASIL DAN PEMBAHASAN}

\section{Kegiatan di Unit Pusdiklat BPPT $[1,2,3]$}

Suatu simulasi untuk menyusun formasi jabatan fungsional perekayasa di suatu unit di Pusdiklat dalam melaksanakan program kegiatan terkait dengan kerekayasaan, pelaksanaan program akan dilakukan pada tahun 2020 , dengan jumlah kegiatan unit pusdiklat pada tahun tersebut sebanyak dua kegiatan program, pada tahun 2021 dengan dua program kegiatan, pada tahun 2022 dengan tiga program, pada tahun 2023 dengan tiga program kegiatan, dan untuk tahun 2024 juga dengan tiga program kegiatan, kontribusi kegiatan program ini mengandung unsur kerekayasaan.

Pada saat ini yaitu tahun 2020 jumlah pegawainya ada sebanyak 32 orang, sedangkan yang memangku jabatan perekayasa ada sebanyak 11 orang, sedangkan untuk dua kegiatan dengan menggunakan persamaan (1) diperoleh kebutuhan personil mencapai 18 orang, demikian pula untuk tiga program kegiatan kerekayasaan ini membutuhkan 22 orang personil. Konfigurasi formasi jabatan fungsional perekayasa pada unit ini secara total berjumlah hanya 11 orang dengan menduduki jabatan perekayasanya sebagaimana dapat dilihat pada Tabel 4

Tabel 4. Formasi Jabatan Fungsional Perekayasa di Unit Pusbindiklat

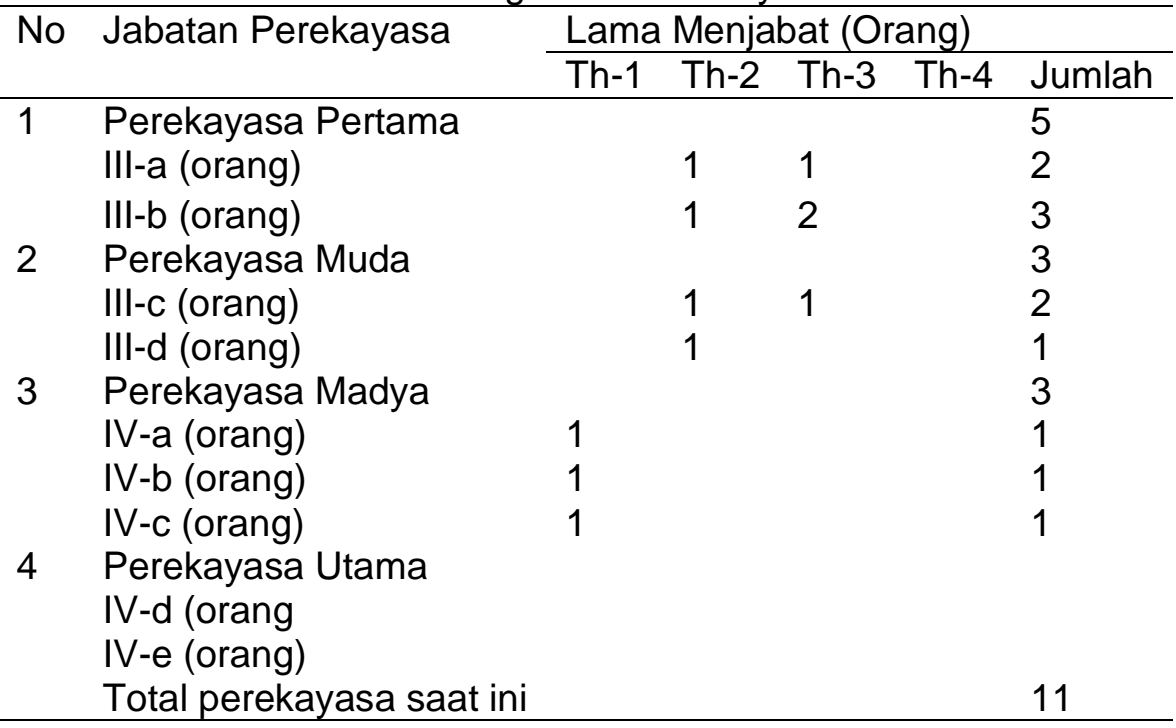

Dari tabel 4 terlihat bahwa jumlah sampai dengan saat ini perekayasa yang berada di unit diklat tersebut sebanyak 11 orang dengan konfigurasinya perekayasa pertama ada sebanyak 5 orang, perekayasa muda 3 orang, perekayasa madya sebanyak 3 orang. Dari tabel ini terlihat bahwa lama menjabat antara 2 dan 3 tahun, untuk yang menjabat 2 tahun pada tahun 2024, jika naik jabatan dengan kondisi normal akan naik satu tingkat diatasnya, sedangkan yang menjabat 3 tahun, maka pada tahun 2023, akan naik jabatan satu tingkat diatasnya. Kondisi kenaikan personil dengan JFP 
ini bersifat bergerak, secara dinamik waktu ke waktu sehingga adanya perubahan kenaikan jabatan dari ke 11 perekayasa pada tahun-tahun tersebut.

Dengan menggunakan persamaan (1), akan diperoleh rencana kebutuhan formasi jabatan fungsional perekayasa ini, yaitu untuk dua program kegiatan, maka dengan menggunakan persamaan 1), diperoleh kebutuhan total formasi jabatan fungsional perekayasa:

Menyusun formasi JFP dengan menggunakan matriks transformasi dapat, dan menggunakan persamaan (3) yaitu refleksi ketersedian perekayasa saat ini yang bersifat bergerak secara dinamis mengikuti perubahan kenaikan jabatannya. Formasi jabatan fungsional perekayasa yang dibutuhkan / lowong atau nett requirement diperoleh dengan menggunakan persamaan (4), untuk memperoleh perhitungan kebutuhan personil atau lowongan yang digambarkan dalam Tabel 2 sebagai berikut.

Tabel 5. Konfigurasi Formasi JFP 2020-2025 di unit Pusdiklat

\begin{tabular}{|c|c|c|c|c|c|c|c|}
\hline \multirow[t]{2}{*}{ No } & \multirow[t]{2}{*}{ Formasi Jab Fung Perekayasa } & \multicolumn{6}{|c|}{ Tahun Berjalan (Orang) } \\
\hline & & 2020 & 2021 & 2022 & 2023 & 2024 & 2025 \\
\hline \multirow[t]{5}{*}{ A } & Rencana Kebutuhan (gross) & & 18 & 18 & 22 & 22 & 22 \\
\hline & Perekayasa pertama $\mathrm{Y}_{1}^{\mathrm{t}}$ & & 9 & 9 & 10 & 10 & 10 \\
\hline & Perekayasa Muda $\mathrm{Y}_{2}{ }_{2}$ & & 5 & 5 & 6 & 6 & 6 \\
\hline & Perekayasa Madya $\mathrm{Y}_{3}{ }_{3}$ & & 3 & 3 & 4 & 4 & 4 \\
\hline & Perekayasa Utama $\mathrm{Y}_{4}^{\mathrm{t}}$ & & 1 & 1 & 2 & 2 & 2 \\
\hline \multirow[t]{5}{*}{ B } & Ketersediaan Formasi JFP (on hand) & 11 & 11 & 15 & 20 & 21 & 21 \\
\hline & Perekayasa pertama $B_{1}$ & 5 & 5 & 7 & 9 & 10 & 10 \\
\hline & Perekayasa Muda $\mathrm{B}_{2}$ & 3 & 3 & 5 & 6 & 6 & 6 \\
\hline & Perekayasa Madya $\mathrm{B}_{3}$ & 3 & 3 & 3 & 4 & 4 & 4 \\
\hline & Perekayasa Utama B4 & & & & 1 & 1 & 1 \\
\hline \multirow[t]{5}{*}{ C } & Kebutuhan Formasi JFP (nett) & & 7 & 3 & 2 & 1 & 1 \\
\hline & Perekayasa pertama $Z_{1}{ }_{1}$ & & 4 & 2 & 1 & 0 & 0 \\
\hline & Perekayasa Muda $Z_{2}{ }_{2}$ & & 2 & 0 & 0 & 0 & 0 \\
\hline & Perekayasa Madya $\mathrm{Z}_{3}{ }_{3}$ & & 0 & 0 & 0 & 0 & 0 \\
\hline & Perekayasa Utama $Z_{4}^{\mathrm{t}}$ & & 1 & 1 & 1 & 1 & 1 \\
\hline \multirow[t]{2}{*}{ D } & Asumsi Formasi JFP (realisasi) & & & & & & \\
\hline & $\begin{array}{l}\text { Perekayasa pertama } \mathrm{S}_{1} \\
\text { Perekayasa Muda } \mathrm{S}_{2} \\
\text { Perekayasa Madya } \mathrm{S}_{3} \\
\text { Perekayasa Utama } \mathrm{S}_{4}\end{array}$ & & & 2 & 2 & 1 & \\
\hline$E$ & Asusmsi penerimaan pegawai baru $\mathrm{S}_{-1}\left({ }^{*}\right)$ & & & 2 & 2 & 1 & \\
\hline
\end{tabular}

Keterangan: Dihitung dengan persamaan $1.2 .3,4$; konsep PRP(MRP) (') : pegawai baru mengarah akan menjadi perekayasa

Dari Tabel 5 terlihat bahwa posisi perekyasa madya pada awal tahun 2021 tersebut sudah memenuhi, karena kebanyakan diperoleh dari hasil inpassing, tetapi untuk perekayasa pertama maupun perekayasa muda masih kurang, oleh karena itu untuk menutupi kekurang personil minimal disediakan rata-rata dua orang pertahun untuk menjadi perekayasa pertama, sehingga pada tahun 2024 semua kegiatan sudah diisi oleh perekayasa, kecuali untuk perekayasa utama baru tersedia hanya 1 orang, hal ini disebabkan kondisi dari strata perekayasa masih berada pada kondisi di madya.

\section{KESIMPULAN}

Untuk menentukan kebutuhan jumlah formasi jabatan fungsional perekayasa, pertama harus diasumsikan nilai rata-rata kebutuhan personil (gross) untuk satu kegiatan kerekayasaan, dalam hal ini dberikan dengan nilai sebanyak 14 orang, dengan asumsi bahwa dalam satu kegiatan dengan tipe organisasinya adalah tipe $\mathrm{B}$, dengan konfigurasi troika sebanyak 3 orang, Kepala kelompok 2 
orang, Kepala sebanyak 3 orang, dan insinyur stafnya sebanyak 6 orang. Jika jumlah kegiatan bertambah lebih dari satu, maka jumlah formasi kebutuhan total perekayasa adalah menggunakan rumus $\mathrm{Y}_{\mathrm{i}}^{\mathrm{t}}=\mathrm{Xi}+4(\mathrm{k}-1)$..[1], dimana $\mathrm{k}$ adalah kegiatan, jika jumlah kegiatan $\mathrm{k}=2$, maka jumlah kebutuhan formasi JFP dengan menggunakan rumus ini sebanyak 18 orang.

Jika, kegiatannya melibatkan instansi luar yang meliputi empat unsur kegiatannya, dan WBS lebih dari 4, serta kegiatannya mencapai waktu minimal 1 (satu) tahun, maka jumlah kebutuhan formasi jabatan kerekayasaan menggunakan rumus $\mathrm{Y}_{\mathrm{i}}^{\mathrm{t}}$, dimana nilai $\mathrm{k}$-nya, umpama $\mathrm{k}=\mathrm{n}$, maka dengan demikian ada unsur luar berarti membutuhkan personil, dengan minimal WBS tambahan dari luar menjadi 5 WBS dengan nilai $k=n+1$.

\section{REFERENSI}

GRUBBSTROM, ROBERT W., Material Requirements Planning and Manufacturing Resource Planning. 2002

KEPUTUSAN KEPALA BADAN PENGKAJIAN DAN PENERAPAN TEKNOLOGI nomor 01/Kp/BPPT/1/2009 , tentang petunjuk teknis Jabatan fungsional Perekayasa dan angka kreditnya, 2009

PERATURAN PERMENPAN-RI Nomor: PER/219/M.PAN/7/2008 Jabatan Fungsional Perekayasa dan Angka Kreditnya Peraturan Bersama Menteri Negara Riset dan Teknologi dan Kepala Badan kepegawaian Negara Nomor 13/M/PBNI I//2008 dan Nomor 22 TAHUN 2008 tentang Petunjuk Pelaksanaan Jabatan Fungsional Perekayasa dan Angka Kreditnya. Jakarta, 2008

REPUBLIK INDONESIA, “Peraturan Perundang-undangan Nomor 11 Tahun 2019 tentang Sistem Nasional IImu Pengetahuan dan Teknologi". Jakarta, 2019.

REPUBLIK INDONESIA, "Peraturan Perundang-undangan Nomor 05 tahun 2014 tentang Aparatur Sipil Negara", Jakarta, 2014.

REPUBLIK INDONESIA, "Peraturan Pemerintah nomor 16 tahun 1994 tentang Jabatan Fungsional Pegawai Negeri Sipil”. Jakarta, 1994.

REPUBLIK INDONESIA “ Peraturan PermenPAN-RB nomor 11 tahun 2017 tentang Manajemen pegawai negeri sipil', Jakarta, 2017

REPUBLIK INDONESIA “ Peraturan PermenPAN-RB nomor 38 tahun 2017, tentang Standar Kompetensi PNS”, Jakarta, 2017

REPUBLIK INDONESIA "Peraturan Presiden nomor 38 tahun 2018 tentang Rencana Induk Riset Nasional tahun 2017-2045". Jakarta, 2018.

REPUBLIK INDONESIA " Peraturan PermenPAN-RB nomor 49 tahun 2018 tentang Manajemen pegawai pemerintah dengan perjanjian kerja', Jakarta, 2018

REPUBLIK INDONESIA “Peraturan PermenPAN-RB nomor 13 tahun 2019 tentang Pengusulan Jabatan Fungsional", Jakarta, 2019

REPUBLIK INDONESIA “Peraturan PermenPAN-RB nomor 1 tahun 2020 tentang Pedoman analisis jabatan dan analisis beban kerja”, Jakarta, 2020

ROBERT L. MATHIS I, JOHN H. JACKSON, Human Resource Management, Southwestern college Publishing., 101.ed., 2003 